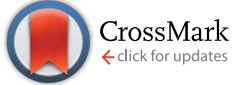

Cite this: Anal. Methods, 2016, 8, 510

\section{Using fluoro modified RNA aptamers as affinity ligands on magnetic beads for sensitive thrombin detection through affinity capture and thrombin catalysis $\dagger$}

\begin{abstract}
Lihua $\mathrm{Hao}^{\mathrm{ab}}$ and Qiang Zhao*ab
Many RNA aptamers against a variety of targets have been selected, and some of the RNA aptamers can have better binding affinity than DNA aptamers. The application of RNA aptamers against thrombin in bio-analysis previously did not attract enough attention due to the high cost in synthesis and poor stability of RNA aptamers, compared with the wide use of DNA aptamers. Here we present a sensitive and specific assay for thrombin by using a nuclease-resistant fluoro (F) modified RNA aptamer (Toggle25) as an affinity ligand on magnetic beads to explore the capability of this RNA aptamer for thrombin detection and expand its application. This RNA aptamer had high binding affinity and good stability. The RNA aptamers were immobilized on the magnetic beads to selectively capture thrombin, and then thrombin cleaved fluorogenic or chromogenic peptide substrates. The measurement of the generated product allowed the final detection of thrombin. This assay reached a detection limit of $10 \mathrm{fM}$ when a fluorogenic substrate was used. Thrombin could be successfully detected in diluted human serum. This work shows that the applied RNA aptamer Toggle-25 is a good alternative to DNA aptamers of thrombin as an affinity ligand, and it can be used in developing assays for thrombin. Other assays for thrombin can be expected by using this RNA aptamer with a different detection format.
\end{abstract}

Received 8th October 2015

Accepted 7th December 2015

DOI: 10.1039/c5ay02665b

www.rsc.org/methods binding affinity in interaction with targets, and the abundance of structures of RNA makes the success of selection of RNA aptamers against some targets easier than DNA aptamers against these targets. The synthesis of a RNA sequence is relatively costly, and more care is needed in preparation and sample handling. ${ }^{3-8}$ Among the reported aptamers, many aptamers are RNA aptamers. ${ }^{3,9-12}$ For some specific targets only RNA aptamers have been selected. For some targets, both DNA aptamers and RNA aptamers are available, but they may show difference in binding strength, binding sites, secondary structure, and binding mechanism. Compared with the wide use of DNA aptamers in bioanalysis and biosensing, the bioanalytical applications of RNA aptamers are still relatively limited as they usually have poor chemical stability and they are more susceptible to nuclease degradation than DNA..$^{5-8,13,14}$ However, RNA aptamers containing certain modifications in the nucleotide sugar residues (e.g. 2' fluoro, $2^{\prime} \mathrm{NH}_{2}$, or $2^{\prime} \mathrm{O}$-methyl modification), phosphates, or bases can have greatly improved stability, and resistance to nuclease degradation. ${ }^{3}$ These modified RNA aptamers can have much higher stability in biological fluids than unmodified RNA aptamers and even DNA aptamers. The modified RNA aptamers have more potential in diagnostic and therapeutic applications than the unmodified RNA aptamers., ${ }^{3,15,16}$ The synthesis of RNA aptamers with such modification has become commercially available with accepted
${ }^{a}$ Institute of Environmental Science, College of Chemistry and Chemical Engineering, Shanxi University, Taiyuan, 030006, China. E-mail: chemzhaoq@hotmail.com; qiangzhao@rcees.ac.cn

${ }^{b}$ State Key Laboratory of Environmental Chemistry and Ecotoxicology, Research Center for Eco-Environmental Sciences, Chinese Academy of Sciences, Beijing, 100085, China $\dagger$ Electronic supplementary information (ESI) available. See DOI: 10.1039/c5ay02665b 
cost, and it is expected that the cost can be further decreased with progress of the technique. The bioanalytical applications of these RNA aptamers are worth exploring taking advantage of their benefits in affinity binding.

Thrombin is a serine protease that plays multifunctional roles in blood coagulation and other physiological processes, an important biomarker for some diseases. ${ }^{17,18}$ Aptamers against thrombin have been widely involved to develop a variety of assays. ${ }^{19}$ One commonly used thrombin-binding aptamer is the 15-mer DNA aptamer (denoted as Apt-15 here, 5'-GGT TGG TGT GGT TGG-3') binding with the fibrinogen binding site of thrombin, and it shows a dissociation constant $\left(K_{\mathrm{d}}\right)$ about $100 \mathrm{nM} .{ }^{20}$ Apt-15 can form a G-quadruplex structure (Fig. S1 in ESI $\dagger$ ). ${ }^{21}$ Another widely used and well investigated aptamer is the 29-mer DNA aptamer (denoted as Apt-29 here, 5'-AGT CCG TGG TAG GGC AGG TTG GGG TGA CT- $\left.3^{\prime}\right),{ }^{21}$ which binds to the heparin-binding exosite of thrombin with a higher affinity $\left(K_{\mathrm{d}}=\right.$ $0.5 \mathrm{nM})$. It is predicted that Apt-29 contains additional basepairs flanking a G-quadruplex motif, suggesting a quadruplex/ duplex structure (Fig. S1 in ESI $\dagger$ ). ${ }^{21}$ RNA aptamers against thrombin are also available. ${ }^{22-24}$ In 1994, Kubik et al. reported a 24 nt RNA aptamer (5'-UCC GGA UCG AAG UUA GUA GGC GGA-3', named R16.24 here) with a dissociation constant about $9.3 \mathrm{nM} .{ }^{22}$ White et al. successfully selected a $25 \mathrm{nt}$ RNA aptamer (named Toggle-25 here) with high binding-affinity for thrombin by using "Toggle" SELEX in 2001. ${ }^{23}$ Toggle-25 contains 2 '-fluorosubstitutions on uracil (U) and cytosine (C) nucleotides, and it is more nuclease resistant than unmodified RNA or DNA aptamers, showing a longer half life in biological fluids. ${ }^{23}$ Toggle-25 exhibits a $K_{\mathrm{d}}$ about $0.5 \mathrm{nM}^{23}$ The crystal structure of Toggle-25 bound with thrombin shows that Toggle-25 binds with the heparin-binding site of thrombin..$^{25,26}$ Toggle-25 has a secondary structure of a stem-loop with an internal bulge (shown in Fig. 1). ${ }^{23,25}$ Compared with the widely applied DNA aptamers of thrombin, RNA aptamers against thrombin have not attracted enough attention, and the use of RNA aptamers in thrombin assays is limited. ${ }^{27-29}$ For RNA aptamer Toggle-25, only a few

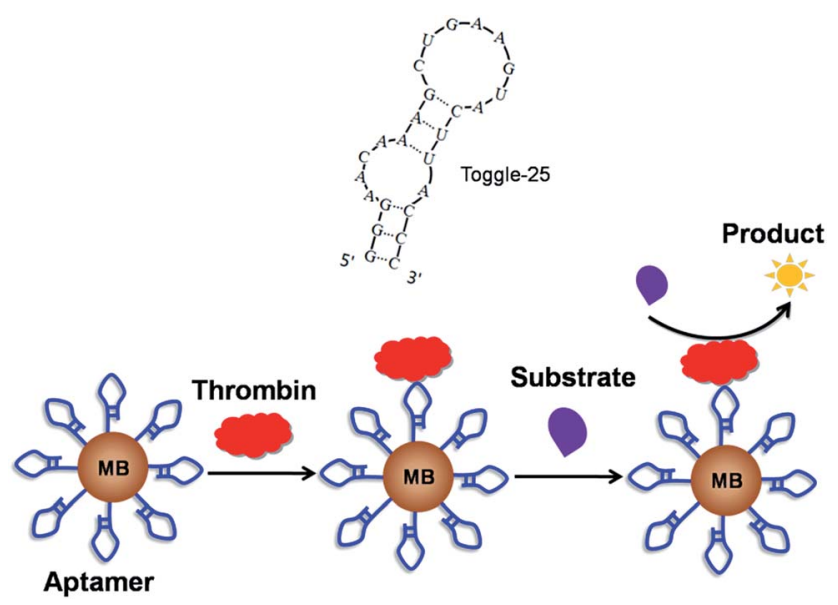

Fig. 1 Schematic diagram of thrombin detection by using RNA aptamer Toggle-25 as an affinity ligand on magnetic beads (MBs) through affinity capture and enzyme reaction. Predicted secondary structure of Toggle-25 is shown. studies reported its potential use for thrombin sensing and molecular interaction study, including surface acoustic wave (SAW) sensor chip with MALDI mass spectrometric analysis and nanometer gap-sized impedance biosensors, ${ }^{30-32}$ and the application of Toogle-25 for thrombin assay development was not well studied.

The aim of this work is to explore and expand the application of Toggle-25 as affinity ligands in assays for thrombin. Here we describe a simple, selective, and sensitive assay for the detection of thrombin with Toggle-25 as the affinity ligand on magnetic beads, taking advantage of previously developed affinity capture and enzyme reaction based assays for thrombin..$^{3-35}$ The used magnetic beads have the advantages of large surface area, simple magnetic separation, and easy immobilization of affinity ligands. ${ }^{36,37}$ Fig. 1 shows the principle of the assay using Toggle-25 as the affinity ligand. Toggle-25 is conjugated on magnetic beads, and then it specifically captures thrombin. After washing and magnetic separation, the thrombin catalyzes the hydrolysis of fluorogenic substrates or chromogenic substrates to generate products. Finally, thrombin is detected by measuring the product.

Our work shows that the Toggle-25 RNA aptamer is a good alternative to DNA aptamers as an affinity ligand in developing assays for thrombin. In our Toggle-25 based assay using chromogenic substrates, thrombin was detected by simple absorbance analysis of the generated product, achieving the detection of thrombin at $0.25 \mathrm{pM}$. The sensitivity of the assay was greatly improved when fluorogenic substrates were used instead due to the high sensitivity of fluorescence analysis, as low as $10 \mathrm{fM}$ thrombin in $100 \mu \mathrm{L}$ of sample was detected. Thrombin was successfully detected without interference from other tested proteins. Furthermore, thrombin in serum samples was also successfully detected with a good recovery by using this nuclease-resistant fluoro modified Toggle-25 aptamer, which was not obtained by using the unmodified RNA aptamer affinity ligands because the unmodified RNA was degraded by nuclease in serum. Compared with a similar assay using DNA aptamers, the assay using Toggle-25 with $\mathrm{F}$ modification as the affinity ligand showed comparable sensitivity. It is believed that the Toggle-25 can be used in other assays for thrombin detection with different formats. This shows that the Toggle-25 RNA aptamer has great promise in bioanalysis and clinical research.

\section{Experimental}

\section{Chemicals and reagents}

Human serum albumin (HSA), hemoglobin from bovine blood, lysozyme and bovine serum albumin (BSA) were purchased from Sigma. Human $\alpha$-thrombin was ordered from Haematologic Technologies Inc. (Essex Junction, VT). Human serum was obtained from Zhongke Chenyu Biotechnology in Beijing. The fluorogenic substrate of thrombin, $N$ - $p$-tosyl-Gly-Pro-Arg-7amido-4-methylcoumarin hydrochloride, and the chromogenic substrate of thrombin, $N$ - $p$-tosyl-Gly-Pro-Arg- $p$-nitroanilide acetate, were purchased from Sigma. Streptavidin coated magnetic beads $\left(1 \mu \mathrm{m}\right.$ in diameter, Dynabeads MyOne ${ }^{\mathrm{TM}}$ Streptavidin C1) were ordered from Invitrogen Dynal. All RNA 
aptamers were synthesized and purified by Takara Biotechnology (Dalian). The biotinylated RNA aptamers (denoted as Toggle-25) against thrombin had the following sequence, $5^{\prime}$ GGG AAC AAA GCU GAA GUA CUU ACC C- $3^{\prime}$ with biotin labeled on $5^{\prime}$ end, and $\mathrm{C}$ and $\mathrm{U}$ bases contained $2^{\prime}$-fluoro modification. ${ }^{23}$ A biotinylated RNA control had the following sequence $5^{\prime}$-GGG AAC AAA GCU GAA GUA CAA ACC C-3' (denoted as Control-25), and $\mathrm{C}$ and $\mathrm{U}$ bases in the control RNA contained $2^{\prime}$-fluoro modification. In addition, a RNA oligonucleotide that had the same sequence of Toggle-25 and did not contain 2 -fluoro modification in $\mathrm{C}$ and $\mathrm{U}$ was synthesized for comparison of affinity and stability, and this RNA oligonucleotide was named Toggle-25-without-F. Biotin was labeled on $5^{\prime}$ end in all RNA oligos. Biotinylated DNA aptamers for thrombin were also used for comparison, and biotin was labeled on $5^{\prime}$ end. The DNA aptamers (Apt-15: 5'-GGT TGG TGT GGT TGG-3'; Apt-29: 5'-AGT CCG TGG TAG GGC AGG TTG GGG TGA CT- $3^{\prime}$ ) were synthesized and purified by Sangon Biotech (Shanghai, China). Solvents and other reagents were of analytical grade. The applied assay buffer was phosphate buffer solution containing $10 \mathrm{mM} \mathrm{Na}{ }_{2} \mathrm{HPO}_{4}$, $2 \mathrm{mM} \mathrm{KH}_{2} \mathrm{PO}_{4}, 2.7 \mathrm{mM} \mathrm{KCl}, 68.5 \mathrm{mM} \mathrm{NaCl}, 2 \mathrm{mM} \mathrm{MgCl} 2$ and $1 \mathrm{mg} \mathrm{mL}^{-1}$ BSA ( $\mathrm{pH}$ 7.5). The washing buffer contained $10 \mathrm{mM}$ $\mathrm{Na}_{2} \mathrm{HPO}_{4}, 2 \mathrm{mM} \mathrm{KH} \mathrm{PO}_{4}, 2.7 \mathrm{mM} \mathrm{KCl}, 68.5 \mathrm{mM} \mathrm{NaCl}, 2 \mathrm{mM}$ $\mathrm{MgCl}_{2}$ and $0.1 \%$ Tween $20(\mathrm{pH} 7.5)$. The enzyme reaction buffer containing $50 \mathrm{mM}$ Tris- $\mathrm{HCl}$ and $1 \mathrm{M} \mathrm{NaCl}(\mathrm{pH}$ 8.5) was used for the enzyme reaction to convert the substrate to the product.

\section{Preparation of RNA aptamer coated magnetic beads}

To obtain RNA aptamer coated magnetic beads, $200 \mu \mathrm{L}$ of streptavidin-coated magnetic beads $\left(10 \mathrm{mg} \mathrm{mL}^{-1}\right)$ in a solution containing $20 \mathrm{mM}$ Tris- $\mathrm{HCl}(\mathrm{pH} 7.5), 2 \mathrm{M} \mathrm{NaCl}$, and $0.1 \%$ Tween 20 was mixed with $200 \mu \mathrm{L}$ of Toggle-25 aptamer $(4.8 \mu \mathrm{M})$ in water, and incubated at room temperature for one hour. The magnetic beads were separated from the solution by using a magnetic separator. The collected aptamer-coated beads were washed three times with $200 \mu \mathrm{L}$ of Tris- $\mathrm{HCl}$ solution $(20 \mathrm{mM}$ Tris-HCl, $150 \mathrm{mM} \mathrm{NaCl}, 2 \mathrm{mM} \mathrm{CaCl}_{2}, 0.1 \%$ Tween 20, pH 7.5) and redispersed in $800 \mu \mathrm{L}$ of Tris- $\mathrm{HCl}$ solution $(20 \mathrm{mM}$ Tris$\mathrm{HCl}, 150 \mathrm{mM} \mathrm{NaCl}, 2 \mathrm{mM} \mathrm{CaCl}, 0.1 \%$ Tween 20, pH 7.5), achieving a magnetic bead suspension with a concentration of $2.5 \mathrm{mg} \mathrm{mL}{ }^{-1}$. Finally, the aptamer-coated bead suspension was stored at $4{ }^{\circ} \mathrm{C}$ prior to use. By measuring the decrease of the aptamer concentration in solution after the aptamer immobilization through absorbance analysis at $260 \mathrm{~nm}$, it was determined that about 477 pmole aptamers were immobilized on $1 \mathrm{mg}$ of magnetic beads. Other RNA aptamers or DNA aptamer coated magnetic beads were prepared by using the same procedure.

\section{Detection of thrombin}

In the assay using the fluorogenic substrate of thrombin, $2 \mu \mathrm{L}$ of aptamer coated magnetic bead suspension at $2.5 \mathrm{mg} \mathrm{mL}^{-1}$ (corresponding to about 2.4 pmole Toggle-25 coated on magnetic beads) were added into $100 \mu \mathrm{L}$ of thrombin at varying concentrations in assay buffer solution and incubated for $30 \mathrm{~min}$ at room temperature under shaking. After that, the magnetic beads were separated and washed with $100 \mu \mathrm{L}$ of washing buffer three times. Then, the magnetic beads were redispersed in $20 \mu \mathrm{L}$ of enzyme reaction buffer containing $264 \mu \mathrm{M}$ fluorogenic substrate of thrombin. After $2 \mathrm{~h}$ incubation at $37{ }^{\circ} \mathrm{C}$ under shaking, the reaction solution was separated from the magnetic beads and added to $80 \mu \mathrm{L}$ of ultrapure water. Finally, the fluorescence intensity of the obtained solution was measured by using a plate reader (Varioskan Flash, Thermo Fisher Scientific, Inc) with an excitation at $370 \mathrm{~nm}$ and an emission at $440 \mathrm{~nm}$ to achieve the final detection of thrombin.

In the assay using a chromogenic substrate of thrombin, a similar procedure was conducted. Thrombin was captured on the aptamer coated magnetic beads and washed by the same process described above. After separation and washing, the magnetic beads were dispersed in $20 \mu \mathrm{L}$ of enzyme reaction buffer containing $375 \mu \mathrm{M}$ chromogenic substrate of thrombin. Following incubation at $37{ }^{\circ} \mathrm{C}$ for $2 \mathrm{~h}$ under shaking, the reaction solution was isolated from the magnetic beads and added to $80 \mu \mathrm{L}$ of ultrapure water. The obtained mixture solution was transferred into a quartz cuvette with a working volume of $50 \mu \mathrm{L}$ and the path length of $1 \mathrm{~cm}$. Finally, the absorbance of the product solution at $405 \mathrm{~nm}$ was measured by using a UV-vis spectrophotometer (HITACHI U3010) to achieve the final detection of thrombin.

\section{Test of assay specificity and sequence specificity}

To investigate the specificity of the assay, other proteins (human serum albumin, hemoglobin, and lysozyme) were tested by using a similar procedure described above for the detection of thrombin. In the assay, $100 \mu \mathrm{L}$ of tested proteins and $2 \mu \mathrm{L}$ of RNA aptamer coated magnetic bead suspension were mixed. The concentration of human $\alpha$-thrombin was $10 \mathrm{pM}$, and the concentration of other tested proteins was all $100 \mathrm{nM}$. Besides, thrombin (10 pM) in the presence of human serum albumin (100 $\mathrm{nM})$, hemoglobin (100 $\mathrm{nM})$ or lysozyme $(100 \mathrm{nM})$ was tested. We also tested the sequence specificity of RNA aptamer Toggle-25 in the assay for thrombin by using the RNA-control (Control-25) coated magnetic beads.

\section{Detection of thrombin in serum samples}

We chose diluted human serum with a binding buffer as a complex sample matrix. In the assay using the fluorogenic substrate, thrombin spiked in 100-fold diluted serum sample at varying concentrations was analyzed by the same procedure for the detection of thrombin in binding buffer solution above.

\section{Results and discussion}

\section{Detection of thrombin using Toggle-25 coated magnetic beads through affinity capture and enzyme reaction}

Thrombin could be detected by using Toggle-25 coated magnetic beads and a fluorogenic substrate, $N$ - $p$-tosyl-Gly-ProArg-7-amido-4-methylcoumarin hydrochloride, following a principle shown in Fig. 1. In the assay, thrombin was captured by the RNA aptamer Toggle-25 on magnetic beads. The affinity 
binding of Toggle-25 to thrombin did not affect the cleavage of the small fluorogenic peptide substrate by thrombin. The thrombin could cleave the fluorogenic substrate at the Arg site to generate a fluorescent product, 7-amido-4-methylcoumarin hydrochloride. The measurement of the product by fluorescence analysis enabled the final detection of thrombin.

We tested the influence of different types of binding solution on thrombin detection (Fig. S2 in ESI $\dagger$ ), including the reported selection buffer containing $20 \mathrm{mM}$ HEPES ( $\mathrm{pH}$ 7.5), $150 \mathrm{mM}$ $\mathrm{NaCl}$ and $2 \mathrm{mM} \mathrm{CaCl}_{2},{ }^{23}$ the buffer containing $20 \mathrm{mM}$ Tris- $\mathrm{HCl}$ (pH 7.5), $150 \mathrm{mM} \mathrm{NaCl}$, and $2 \mathrm{mM} \mathrm{CaCl}_{2}$, the buffer containing $20 \mathrm{mM}$ Tris- $\mathrm{HCl}$ (pH 7.5), $150 \mathrm{mM} \mathrm{NaCl}$, and $2 \mathrm{mM} \mathrm{MgCl}_{2}$, and the phosphate buffer solution containing $10 \mathrm{mM} \mathrm{Na} \mathrm{HPO}_{4}$, $2 \mathrm{mM} \mathrm{KH} \mathrm{KO}_{4}, 2.7 \mathrm{mM} \mathrm{KCl}, 137 \mathrm{mM} \mathrm{NaCl}, 2 \mathrm{mM} \mathrm{MgCl}{ }_{2}$ ( $\mathrm{pH}$ 7.5). The results show that these four types of binding buffer solutions did not show remarkable difference in the obtained signals. All the buffer solutions could be used for analysis of thrombin. We chose phosphate solution as the binding buffer solution in the assay as it is close to the physiological condition. We further examined the influence of the concentration of $\mathrm{NaCl}$ and $\mathrm{MgCl}_{2}$ in assay buffer solution. A higher signal was obtained when $\mathrm{NaCl}$ at $68.5 \mathrm{mM}$, and increasing the concentration of $\mathrm{NaCl}$ caused a decrease of obtained signals (Fig. S3 in ESI $\dagger$ ). The high concentration of $\mathrm{NaCl}$ in assay buffer may reduce the binding strength of the aptamer. $\mathrm{MgCl}_{2}$ did not show a great effect on the obtained signals. Buffer $\mathrm{pH}$ did not have large influence on affinity capture of thrombin in the range from 6.5 to 9.0. Therefore, the optimized phosphate buffer solution ( $\mathrm{pH} 7.5$ ) containing $68.5 \mathrm{mM} \mathrm{NaCl}, 2 \mathrm{mM} \mathrm{MgCl} 2$ and $1 \mathrm{mg} \mathrm{mL}^{-1}$ BSA was applied as the assay buffer. Experiments also showed $30 \mathrm{~min}$ of incubation at room temperature $\left(20{ }^{\circ} \mathrm{C}\right)$ was sufficient for the affinity capture of thrombin with the Toggle-25 coated magnetic beads.

Under the optimized conditions, we successfully detected thrombin at varying concentrations. The increase of the fluorescence signal at $440 \mathrm{~nm}$ over the blank shows a good linear relationship with the concentrations of thrombin ranging from $0.01 \mathrm{pM}$ to $25 \mathrm{pM}\left(y=42.08 x, R^{2}=0.9994\right)$ (Fig. 2). The detection limit of thrombin reached $10 \mathrm{fM}$, which was determined by signal change over the blank being higher than three times the deviation of the blank signal. The amount of aptamer coated on magnetic beads was excessive for the tested range of thrombin as about 2.4 pmole of Toggle-25 on magnetic beads $(2 \mu \mathrm{L}$ of Toggle-25 coated magnetic bead suspension at $2.5 \mathrm{mg} \mathrm{mL} \mathrm{mL}^{-1}$ ) was applied in $100 \mu \mathrm{L}$ of assay buffer. When the thrombin concentration was higher than $25 \mathrm{pM}$, the used fluorogenic substrate was completely converted to the product, generating a saturated signal. Application of more peptide substrate can extend up the linear range.

In addition, chromogenic substrates could also be used in the Toggle-25 capture based assay for thrombin by taking advantage of simplicity of absorbance analysis. We chose the same experimental conditions for affinity capture of thrombin that were employed in the assay using the fluorogenic substrate. In the enzyme reaction, thrombin cleaved the chromogenic substrate of $N$ - $p$-tosyl-Gly-Pro-Arg- $p$-nitroanilide at the Arg site, generating $p$-nitroaniline, which was detected by measuring the

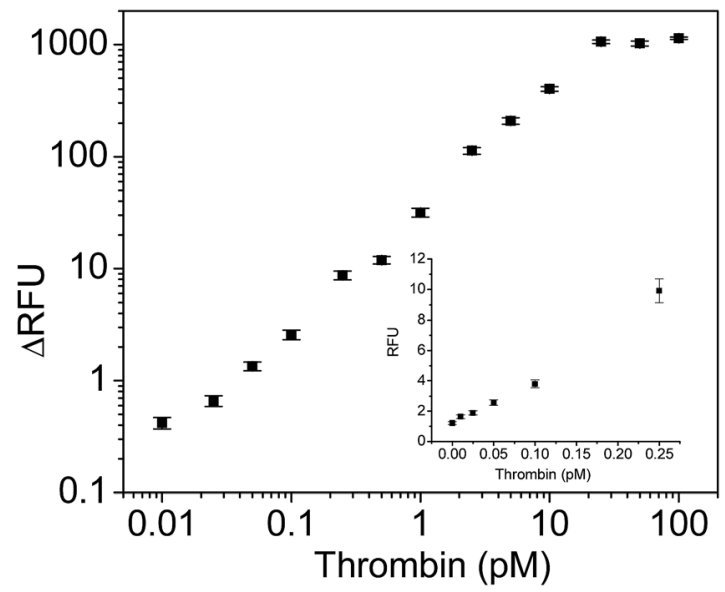

Fig. 2 Detection of thrombin by using Toggle-25 coated magnetic beads and fluorogenic substrates. RFU: relative fluorescence unit. The relationship between the obtained net fluorescence increase ( $\triangle R F U)$ at $440 \mathrm{~nm}$ over blank and the concentration of thrombin was shown. The inset shows the obtained fluorescence signals from the blank and low concentrations of thrombin.

absorbance at $405 \mathrm{~nm}$. Thrombin at varying concentrations was detected by measuring the change of absorbance at $405 \mathrm{~nm}$ (Fig. 3). The linear range for thrombin detection with Toggle-25 coated beads and the chromogenic substrate was from $0.25 \mathrm{pM}$ to $25 \mathrm{pM}$ with a detection limit of $0.25 \mathrm{pM}\left(y=0.0234 x, R^{2}=\right.$ $0.9999)$. The obtained sensitivity in the assay using Toggle-25 coated beads and the chromogenic substrate is lower than that obtained by the assay using Toggle- 25 modified beads and the fluorogenic substrate due to the lower sensitivity in absorbance analysis than fluorescence analysis.

The obtained sensitivity in our assay using RNA aptamer Toggle-25 is comparable to or better than that previously reported in many assays using DNA or RNA aptamers against

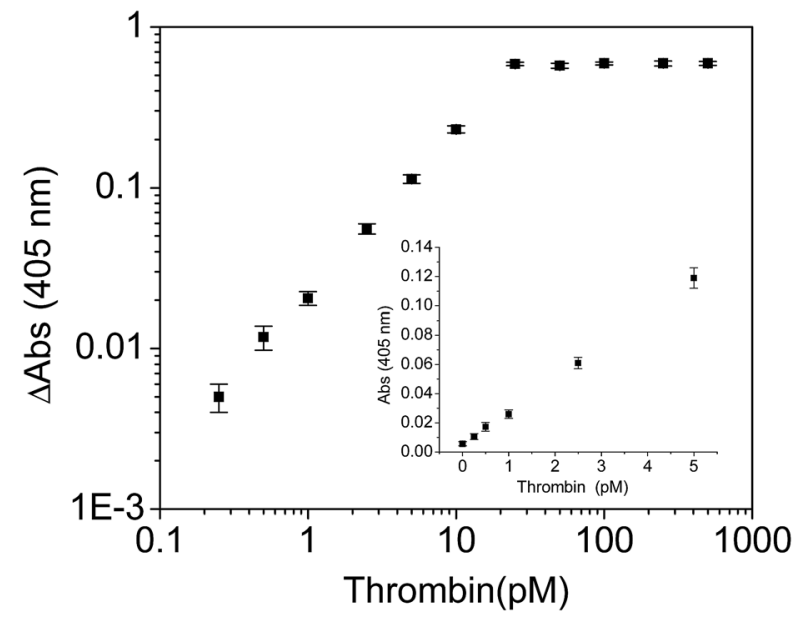

Fig. 3 Detection of thrombin by using Toggle-25 coated magnetic and chromogenic substrates. The relationship between the absorbance (Abs) increase ( $\Delta$ Abs) at $405 \mathrm{~nm}$ over blank and the concentration of thrombin was shown. The inset shows the obtained absorbance signals from the blank and low concentrations of thrombin. 
thrombin in different formats. ${ }^{5-8,14,19,27-29}$ The sensitivity in this assay is close to that obtained in our previously developed assays using DNA aptamers (Apt-15 or Apt-29) as affinity ligands. ${ }^{3-35}$ As a comparison, when the DNA aptamers Apt-15 or Apt-29 instead were conjugated on the magnetic beads and used as affinity ligands, a similar sensitivity was obtained for thrombin detection (shown in Fig. S4 in ESI $\dagger$ ). The results show that the RNA aptamer Toggle-25 is a good alternative to the DNA aptamers in assay development for thrombin detection. Compared with the assay using DNA aptamers, the high cost of synthesis of RNA aptamers is one limitation of this assay using Toggle-25. However, the required amount of the RNA aptamers in our assay is not large, and the applied amount of RNA aptamers can be further reduced, so the cost of using RNA aptamers can be accepted in assay development.

\section{Test of assay specificity and sequence specificity}

To investigate the specificity of the assay, human serum albumin (HSA), hemoglobin from bovine blood, and lysozyme were tested in the assay using fluorogenic substrates (Fig. 4). The tested proteins did not cause interference in the assays. The presence of a high concentration of the tested proteins did not interfere in the detection of thrombin in the assays. The results show that the assay for thrombin has good selectivity, which can be attributed to the selective binding of thrombin with Toggle25 in the capture procedure and the specific recognition of the thrombin substrate in the enzyme reactions.

The sequence specificity of the RNA aptamer was tested by assessing thrombin with RNA control (Control-25, 5'-GGG AAC AAA GCU GAA GUA CAA ACC C-3') coated magnetic beads. Compared with the sequence of Toggle-25, only two $U$ bases of Toggle-25 were substituted with two A bases in Control-25,

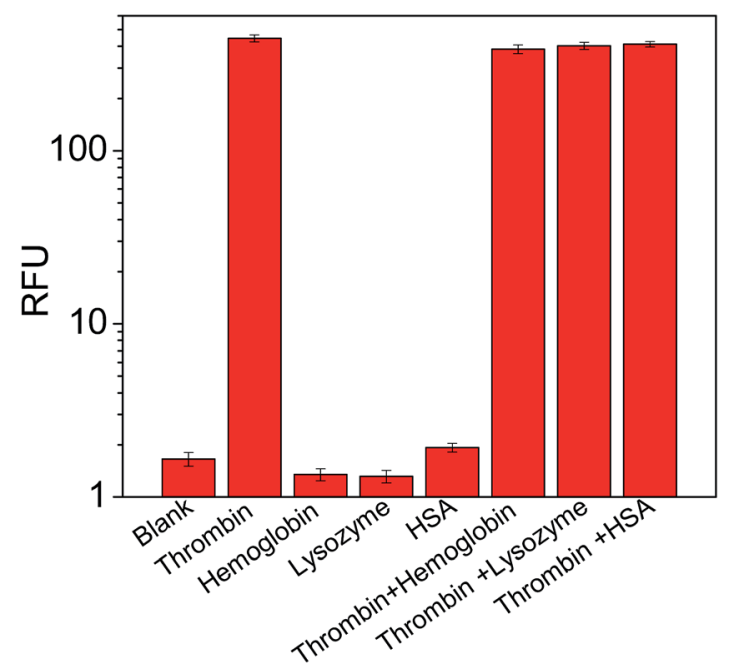

Fig. 4 Specificity test in the assay using Toggle-25 coated magnetic beads and fluorogenic substrates. The concentration of human thrombin was $10 \mathrm{pM}$, and the concentration of human serum albumin, hemoglobin and lysozyme was all $100 \mathrm{nM}$. Thrombin (10 pM) in the presence of human serum albumin (100 nM), hemoglobin (100 nM) or lysozyme $(100 \mathrm{nM})$ was also tested. shown in underline and bold formats in the Control-25 sequence. The Control-25 coated magnetic beads could not well capture thrombin in the assay, and only very low signals over the blank were observed (Fig. 5). The result shows that the binding between Toggle-25 and thrombin is highly dependent on the sequence of Toggle-25, consistent with the previous report. $^{23}$

In addition, Toggle-25 without containing $2^{\prime}$-fluoro modification in $\mathrm{U}$ and $\mathrm{C}$ bases (Toggle-25-without-F) was also tested. The RNA Toggle-25-without-F was coated on magnetic beads following the same procedure for immobilization of Toggle-25. Thrombin could be detected when Toggle-25-without-F coated magnetic beads were used instead of Toggle- 25 coated magnetic beads in the binding buffer solution, and the obtained sensitivity is close to that obtained in the assay using Toggle-25 modified magnetic beads (Fig. S5 in ESI $\dagger$ ). The result shows that Toggle-25 without containing 2 -fluoro modification can still retain the binding affinity to thrombin in the binding buffer solution.

\section{Detection of thrombin in complex samples}

To test the performance of the assay for complex samples, a diluted human serum sample was chosen as the sample matrix. We tested the feasibility of the assay using Toggle-25 coated magnetic beads and fluorogenic substrates for thrombin spiked in diluted serum samples. The human serum sample was 100-fold diluted with binding buffer solution, and then thrombin was spiked into the dilute serum sample solution. Thrombin could be well detected in the 100-fold diluted human serum sample matrix. $10 \mathrm{fM}$ of thrombin could still be detected in the sample matrix (Fig. 6). The recovery of the spiked thrombin ranged from $94 \%-107 \%$. In a 20 -fold diluted serum sample the recovery of thrombin became $70 \%$, which was possibly due to the high concentrations of protein species in 20-fold diluted serum, the larger effect of the sample matrix, or inhibitors present in serum samples. The results show that our

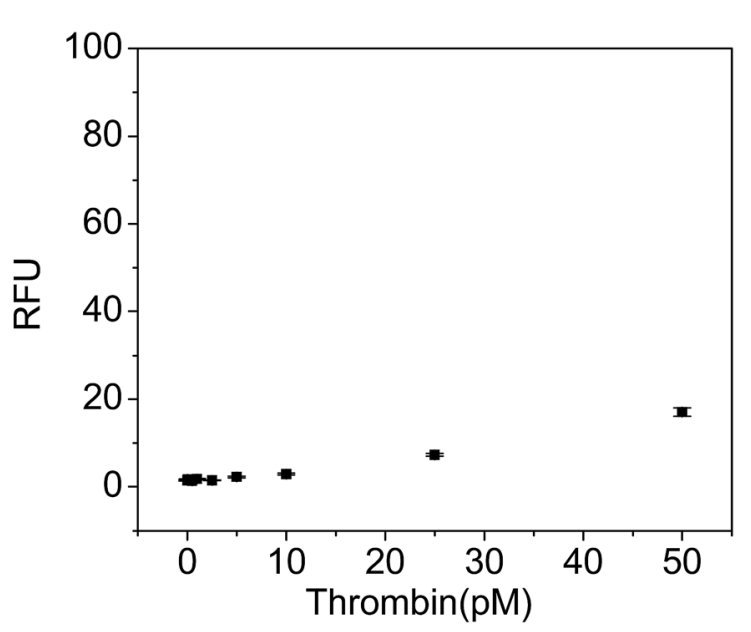

Fig. 5 Test of sequence specificity of Toggle-25 in affinity binding with thrombin by using Control-25 coated magnetic beads and the fluorogenic substrate in the assay for varying concentrations of thrombin. 


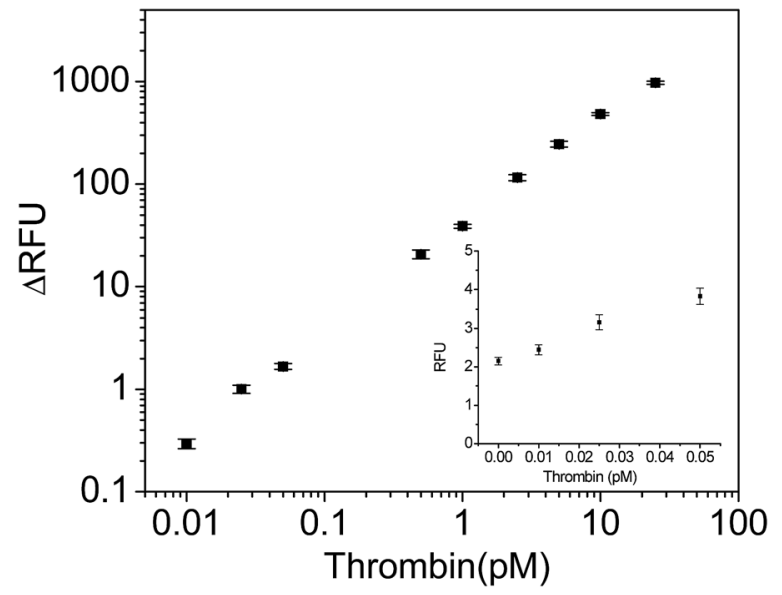

Fig. 6 Detection of thrombin in a 100-fold diluted human serum sample. The inset shows the obtained fluorescence signals from the blank and low concentrations of thrombin.

assay can be used for thrombin detection in a complex sample matrix.

In contrast, Toggle-25-without-F coated beads failed to detect thrombin spiked in a diluted serum sample (Fig. S5 in ESI $\dagger$ ) though it retained good binding affinity to thrombin in the binding buffer solution. Toggle-25-without-F did not contain $2^{\prime}$ fluoro modification in bases, and it was rapidly degraded by nuclease in the serum sample, so Toggle-25-without-F coated beads could not be used to detect thrombin in the serum sample. The result shows the 2 '-fluoro modification in the RNA aptamer greatly improves the stability of Toggle-25 in the complex sample matrix. Toggle-25 with 2 '-fluoro modification is more suitable for thrombin analysis in complex samples. ${ }^{23} \mathrm{~A}$ previous study also shows that Toggle-25 with $\mathrm{F}$ modification shows better half-life in biological fluids than unmodified RNA and DNA aptamers. ${ }^{23}$ The RNA aptamer Toggle-25 with F modification shows advantages in target detection in a complex sample matrix as it has good stability and good nuclease resistance.

\section{Conclusions}

In summary, we reported the use of RNA aptamer Toggle-25 as an affinity ligand in an assay for thrombin based on affinity capture and subsequent enzyme reaction. Toggle-25 contained 2 -fluoro modification in $\mathrm{C}$ and $\mathrm{U}$ bases, showing nuclease resistance. In the assay, thrombin was captured by the Toggle25 coated magnetic beads, and then catalyzed the hydrolysis of the substrate (fluorogenic substrate or chromogenic substrate) to product. The assay using a fluorogenic substrate showed high sensitivity, and enabled the detection of thrombin at 10 fM. RNA aptamer Toggle-25 showed quite good stability in a complex sample matrix due to 2 -fluoro modification in $\mathrm{C}$ and $\mathrm{U}$, allowing for the detection of thrombin in serum samples. RNA aptamer Toggle-25 is a good alternative to the DNA aptamers against thrombin in assay development as it has good stability and high binding affinity and specificity, though the cost of synthesis of RNA aptamers is higher than DNA aptamers. It is expected that this thrombin-binding RNA aptamer can be used for target analysis with other detection strategies to expand its application in bioanalysis and biomedical research.

\section{Acknowledgements}

This work was supported by the National Natural Science Foundation of China (grant no. 21222503, 21435008) and Outstanding Youth Talents Program of Shanxi Province.

\section{References}

1 A. D. Ellington and J. W. Szostak, Nature, 1990, 346, 818-822.

2 C. Tuerk and L. Gold, Science, 1990, 249, 505-510.

3 The Aptamer Handbook, Functional Oligonucleotides and Their Applications, ed. S. Klussmann, Wiley-VCH, Weinheim, 2006.

4 F. Radom, P. M. Jurek, M. P. Mazurek, J. Otlewski and F. Jeleń, Biotechnol. Adv., 2013, 31, 1260-1274.

5 J. Liu, Z. Cao and Y. Lu, Chem. Rev., 2009, 10, 1948-1998.

6 F. Li, H. Zhang, Z. Wang, A. M. Newbigging, M. S. Reid, X. F. Li and X. C. Le, Anal. Chem., 2015, 87, 274-292.

7 A. B. Iliuk, L. Hu and W. A. Tao, Anal. Chem., 2011, 83, 44404452.

8 E. J. Cho, J.-W. Lee and A. D. Ellington, Annu. Rev. Anal. Chem., 2009, 2, 241-264.

9 P. Sundaram, H. Kurniawan, M. E. Byrne and J. Wower, Eur. J. Pharm. Sci., 2013, 48, 259-271.

10 S. C. B. Gopinath, Anal. Chim. Acta, 2009, 636, 117-128.

11 N. S. Que-Gewirth and B. A. Sullenger, Gene Ther., 2007, 14, 283-291.

12 K. N. Kang and Y. S. Lee, Adv. Biochem. Eng./Biotechnol., 2013, 131, 153-169.

13 P. S. Lau, C. K. Lai and Y. Li, ChemBioChem, 2013, 14, 987992.

14 M. Citartan, S. C. B. Gopinath, J. Tominaga, S. C. Tan and T. H. Tang, Biosens. Bioelectron., 2012, 34, 1-11.

15 D. W. Drolet, L. Moon-McDermott and T. S. Romig, Nat. Biotechnol., 1996, 14, 1021-1025.

16 N. Derbyshire, S. J. White, D. H. J. Bunka, L. Song, S. Stead, J. Tarbin, M. Sharman, D. Zhou and P. G. Stockley, Anal. Chem., 2012, 84, 6595-6602.

17 Thrombin: Physiology and Disease, ed. M. E. Maragoudakis and N. E. Tsopanoglou, Springer Science, New York, 2009.

18 S. R. Coughlin, Thromb. Haemostasis, 2005, 3, 1800-1814.

19 B. Deng, Y. Lin, C. Wang, F. Li, Z. Wang, H. Zhang, X. F. Li and X. C. Le, Anal. Chim. Acta, 2014, 837, 1-15.

20 L. C. Bock, L. C. Griffin, J. A. Latham, E. H. Vermaas and J. J. Toole, Nature, 1992, 55, 564-566.

21 D. M. Tasset, M. F. Kubik and W. Steiner, J. Mol. Biol., 1997, 272, 688-698.

22 M. F. Kubik, A. W. Stephens, D. Schneider, R. A. Marlar and D. Tasset, Nucleic Acids Res., 1994, 22, 2619-2626.

23 R. White, C. Rusconi, E. Scardino, A. Wolberg, J. Lawson, M. Hoffman and B. Sullenger, Mol. Ther., 2001, 4, 567-573. 
24 X. M. Liu, G. J. Cao, H. M. Ding, D. J. Zhang, G. Yang, N. L. Liu, M. Fan, B. F. Shen and N. S. Shao, FEBS Lett., 2004, 562, 125-128.

25 S. B. Long, M. B. Long, R. R. White and B. A. Sullenger, RNA, 2008, 14, 2504-2512.

26 M. L. Jeter, L. V. Ly, Y. M. Fortenberry, H. C. Whinna, R. R. White, C. P. Rusconi, B. A. Sullenger and F. C. Church, FEBS Lett., 2004, 568, 10-14.

27 Y. Jiang, X. Fang and C. Bai, Anal. Chem., 2004, 76, 52305235.

28 Y. Li, H. J. Lee and R. M. Corn, Anal. Chem., 2007, 79, 10821088.

29 Y. Chen, K. Nakamoto, O. Niwa and R. M. Corn, Langmuir, 2012, 28, 8281-8285.
30 T. M. A. Gronewold, S. Glass, E. Quandt and M. Famulok, Biosens. Bioelectron., 2005, 20, 2044-2052.

31 U. Schlecht, A. Malavé, T. Gronewold, M. Tewes and M. Löhndorf, Anal. Chim. Acta, 2006, 573-574, 65-68.

32 G. Treitz, T. M. A. Gronewold, E. Quandt and M. Zabe-Kühn, Biosens. Bioelectron., 2008, 23, 1496-1502.

33 Q. Zhao and X. Wang, Biosens. Bioelectron., 2012, 34, 232237.

34 Q. Zhao, X. F. Li and X. C. Le, Anal. Chem., 2011, 83, 92349236.

35 Q. Zhao and J. Gao, Chem. Commun., 2013, 49, 7720-7723. 36 V. Mani, B. V. Chikkaveeraiah and J. F. Rusling, Expert Opin. Med. Diagn., 2011, 5, 381-391.

37 Y. Zhang and D. Zhou, Expert Opin. Med. Diagn., 2012, 6, 565-571. 